\title{
HYNEK BÍM - SBÍRKA DUCHOVNÍCH PÍSNÍ Z VNOROV
}

Sběratelská činnost je pro výzkum písně nejen prostředkem, jak ji uchovat a vyhodnotit, ale také cestou k poznání života lidu v určité oblasti. Nejde však jen o píseň lidovou, která byla předávána z generace na generaci přetváŕela se a existovala $\mathrm{v}$ určité společenské situaci, ale také o všechny vlivy, které ji formovaly. Do této oblasti patří také písně duchovní. Ačkoli jsou duchovní písně zkoumány především z pohledu literární a hudební vědy, nelze je ponechat ani mimo zájem etnomuzikologie.

Předmětem této studie je popsat a analyzovat soubor duchovních písní uložený pod signaturou A1084 v Etnologickém ústavu akademie věd České republiky v Brně, jak je zachytil Hynek Bím při svých opakovaných sběrech v obci Vnorovy ${ }^{1}$ 17. záŕí 1911, 24. záŕí 1911 a 1. října 1911. Jak napsal Hynek Bím v dopise z 12. prosince 1909 Leoši Janáčkovi „,Porovnávaji-li se písně v kancionálu notované s pisněmi Znorovskými z úst zpěváků, jevi se jako kostra živá píseñ - tak asi jako je tomu mnohých písni ve sbírce Sušilově. "2 Podkladem pro srovnání se tedy stal kancionál Jana Josefa Božana Slaviček rájskỷ z roku 1719, který byl členy farnosti využíván při bohoslužbách. Velmi důležitý je však i pohled na kancionál jako na zpěvník, který nám předává písně z předchozích období. V konečném důsledku je však výsledná podoba duchovních písní ovlivňována jeho samotnými tvůrci i osobou, která píseň interpretuje.

1 Samotný název obce prodělal mnoho změn. Vnorovy byly označovány jako Norow, Unirov, Wznorowy a do roku 1925 byl oficiální název obce Znorovy, z německého Znorow. Také proto ještě Bím označuje soubor písní jako Znorovské písně kostelni. Více viz DVORSKÝ, Josef. Vnorovské proměny: 750 let: 1249-1999. Vnorovy: Obecní úr̆ad Vnorovy, 1999. Brno: Masarykova univerzita. Filozofická fakulta. Ústav hudební vědy, 1999, s. 123. Slaviček rájský, jako přesný přepis původního názvu a dále viz edice kancionálu KOSEK, Pavel - MALURA, Jan. Slaviček rájský Jana Josefa Božana a česká duchovní píseñ vrcholného středověku. Brno: Host, 1999. 


\section{Sběratelská činnost Hynka Bíma}

O životě Hynka Bíma (5. 3. 1874 - 30. 12. 1958) bylo napsáno již mnohé, ${ }^{4}$ přesto považuji pro potřeby této studie představit alespoň rámcově jeho sběratelskou činnost. Na to, že se Bím tak aktivně věnoval sběratelské činnosti, mělo pravděpodobně vliv hned několik faktorů. Jedním z nich byl samotný zájem veřejnosti o lidové umění, které by podpořilo národní uvědomění. Tak to také zaznamenává ve vzpomínkách na svou sběratelskou činnost Františka Kyselková. „Zušlechtujeme a zabezpečujeme svioj krásný jazyk, máme bohatý národní kroj, máme ušlechtilé národní zvyky a obyčeje a nade vše nevysýchajicí zdroj krásných národnich pisni. " ${ }^{5}$ Dalším klíčovým faktorem byl především již zmíněný kontakt s Leošem Janáčkem. Lze s určitostí tvrdit, že to byl právě Janáček, který svůj zápal pro lidovou píseň šíril mezi žáky učitelského ústavu. ${ }^{6}$ Kladný ohlas Leoše Janáčka a Františka Bartoše na jeho první sesbírané písně z Ivančicka ${ }^{7}$ patrně také podpořil Bímovy sběratelské snahy. Františka Bartoše pak jeho sběry zaujaly natolik, že do své třetí sbírky Národní písně moravské v nově nasbírané ${ }^{8}$ obsahující 794 písní z Brněnska a Horácka zařadil celkem třicet tř̌i písní.

Na realizaci Národopisné výstavy českoslovanské, která se konala roku 1895 v Praze, se ale Bím prímo nepodílel. Lze ale předpokládat, že tato událost podnítila, stejně jako u ostatních sběratelů, jeho sběratelskou činnost. V roce 1902 vzešel podmět $\mathrm{z}$ vídeňského nakladatelství Universal Edition k zahájení sběratelské akce na rakouském území monarchie. Záhy však převzala veškeré řizení tohoto rozsáhlého projektu vláda. Akce Das Volkslied in Österreich byla řizena z centrály ve Vídni a realizována výbory jednotlivých zemí monarchie. Sběry pak byly realizovány Pracovními výbory, jejichž počet se v jednotlivých zemích lišil. Na našem území začala sběratelská akce roku 1906. Vznikla zde sekce pro Čechy, Moravu a Slezsko a k ní byly přidruženy výbory pro německy mluvící oblasti na českém území. ${ }^{9}$ Předsedou Pracovního výboru pro českou píseň v Čechách byl jmenován Otakar Hostinský, do výboru pro vytvoření Pracovního výboru pro

4 Více např. VYSLOUŽIL, Jiří. Hynek Bím (K osmdesátinám významného sběratele lidových písní). Český lid 41, 1954, s. 51-55; BROUČEK, Stanislav - JEŘÁBEK, Richard (eds.). $L i$ dová kultura: národopisná encyklopedie Čech, Moravy a Slezska. Sv. 3, Praha: Mladá fronta, 2007. SMÉKALOVÁ, Kateřina. Sbirka duchovnich písni z Vnorov. Brno: Masarykova univerzita. Filozofická fakulta. Ústave evropské etnologie, 2009.

5 KYSELKOVÁ, Františka. Jak jsem sbirala národní písně. Brno, 1941, s. 3.

6 Hynek Bím absolvoval učitelský ústav v Brně mezi léty 1888 a 1892, u L. Janáčka navštěvoval hodiny zpěvu a varhan.

7 „Některé sebrané pisně ukázal jsem p. řed. L. Janáčkovi a p. radovi Frant. Bartošovi. Divili se, že se mě podařilo nalézti ještě v Ivančicích a v okoli Ivančic tak hodnotné písně. "Viz TONCROVÁ, op. cit., s. 7.

8 BARTOŠ, František - JANÁČEK, Leoš. Národní písně moravské v nově nasbírané. Praha: Česká akademie císaře Františka Josefa pro vědy, slovesnost a umění, 1899-1901.

9 Zájem však nebyl pouze o sběr písní, ale i o další oblasti lidové kultury. Do čela dialektologických výzkumů se postavil František Autrata, studiem lidové architektury byl pověřen Dušan Jurkovič, Jan Vyhlídal se věnoval duchovní kultuře a každodennímu životu lidu. 
českou píseň na Moravě a ve Slezsku byl jmenován Leoš Janáček. Za svoje spolupracovníky ve výzkumu lidové písně si mimo Bíma, který měl mapovat západní Moravu, zvolil Martina Zemana pro oblast Slovácka a pro Slezsko Metoděje Hrazdiru. Tito hlavní členové Pracovního výboru potom spolupracovali s jednotlivými sběrateli. Roku 1918 se stal členem výboru Pavel Váša, Janáčkův dlouholetý spolupracovník a spoluautor sbírky Moravské pisně milostné ${ }^{10}$. Na Janáčkovu žádost vytvořil Bím seznam nasbíraných písní, které také demonstrují jeho usilovnou snahu zaznamenat co největší množství písní z určité oblasti. V rámci činnosti Pracovního výboru pro českou národní píseň na Moravě a ve Slezsku sbíral především na Slovácku a Valašsku. ${ }^{11}$

Za svého pobytu ve Valašské Bystřici upravil Bím texty a doplnil melodie k souboru valašských písní, které shromáždil tamní učitel František Bobek. Vznikla tak jedna z prvních monografí mapující písňový repertoár v jedné obci. Od roku 1909 začali členové Pracovního výboru zaznamenávat písně pomocí Edisonova fonografu. Bím společně s Františkou Kyselkovou pořídil nejvíce záznamů mezi léty 1910 až 1911 . Zvláště cennými jsou rukopisné zápisy nástrojové hry hudců z Popova na jižním Valašsku. V rámci výzkumu se Bím soustřed’oval na sběr z oblasti západního Slovenska, ale také zaznamenával písně sezónních slovenských dělníků pracujících na Moravě.

Činnost všech členů pracovního výboru byla utlumena vypuknutím 1 . světové války. Z plánovaných několika sbírek, které měly dokumentovat píseň na českém území, byly vydány pouze dvě. Po Janáčkově smrti sešitově vycházely Moravské písně milostné ${ }^{12}$ a roku 1930 a 1937 byly vydány Gustavem Jungbauerem německé písně z Pošumaví Volkslieder aus dem Böhmerwalde ${ }^{13}$. Janáček sice uspořádal první díl plánované edice, ale ani ta nikdy nebyla dána do tisku. Navíc bylo kvưli této edici zničeno i velké množství Bímem zapsaných písní. „, Později navíc velmi nelibě nesl zjištění, že originály jeho zápisư písni byly při prrípravě sbirky milostných písni upravovatelem, možná tedy také samotným Janáčkem, rozstřihány a následně podle potřeby nalepovány na nové papiry." 14

Bímova systematická sběratelská činnost, nepočítáme-li sběr vojenských písní po nástupu do vojenské služby, byla zcela přerušena. Opět se k zaznamenávání písní vrátil až po propuštění z armády roku 1917. Po pádu Rakousko - uherské monarchie byl sice projekt Das Volkslied in Österreich zastaven, avšak na jeho základech byl vytvořen 20. února 1919 Státní ústav pro lidovou píseň a Bím byl jmenován členem Pracovního výboru pro českou lidovou píseň na Moravě.

10 JANÁČEK, Leoš - VÁŠA, Pavel. Moravské písně milostné. Praha: Státní ústav pro lidovou píseň v ČSR, 1930 - 1937.

11 JANÁČEK, Leoš. O lidové písni a lidové hudbě: dokumenty a studie. Jiří Vysloužil (ed.). Praha: Státní nakladatelství krásné literatury, hudby a umění, 1955, s. 57-78. JANÁČEK - VÁŠA, op. cit., 1930.

13 JUNGBAUER, Gustav. Volkslieder aus dem Böhmerwalde. Díl 1, 2. Praha: Ústav pro lidovou píseň v ČSR, 1930, 1937.

14 TONCROVÁ, op. cit., s. 26. 
Po svém odchodu do slovenské Skalice, kde působil jako ředitel nově založené dívčí měštanské školy, pokračoval ve sběru písní v daleko menší míře, než tomu bylo v předválečném období. Roku 1921 byl jmenován také členem Pracovního výboru pro slovenskou lidovou píseň. Roku 1927 byl Bím Janáčkem pověřen, aby podrobněji mapoval provozování hudecké hudby v oblasti Myjavy a zajistil kontakty pro další spolupráci, především co se týče skupiny hudců, která by se měla účastnit výstavy Musik in Völkern ve Frankfurtu. ${ }^{15}$ Jeho sběratelskou činnost ukončuje období po roce 1934, kdy odešel ze Skalice do Tišnova.

Mimo Bartošovy sbírky mu byly otištěny pouze zápisy v Janáčkových a Vášových Písnich moravských ${ }^{16}$ a ve dvoudílné sbírce Karla Vetterla Lidové písně a tance z Valašskokloboučska ${ }^{17}$. Samostatně byly publikovány Bímovy Písně $z$ Hustopečska ${ }^{18}$ a sbírka Valašské a slovenské lidové pisné ${ }^{19}$. Spíše k popularizaci lidové písně byl vydán Zpěvník národnich pisni ${ }^{20}$ a slovenská obdoba české sbírky Slovenské národné piesne. ${ }^{21}$

Během svého života shromáždil Bím fond 4076 písní. Do roku 1899 prováděl sběry především na Ivančicku a Oslavansku, kde zaznamenal 325 písní. V letech 1897 až 1898 zaznamenal 67 písní v Náměšti nad Oslavou a v Hluboké u Náměště. Roku 1899 znamenal 112 písní z Džbánic a tentýž rok na Krumlovsku 144 písní. Na Tišnovsku, kde pobýval roku 1900, zapsal celkem 186 písní. ${ }^{22}$ Toto velké množství textů a melodií svědčí nejen o Bímově píli, ale především o organizaci a vytvoření jednotného systému v záznamu písní. Používal moderní sběratelské metody, vždy usiloval o zmapování celého repertoáru zpěváka a snažil se zachytit metricko-rytmické změny a zaznamenat je do notového zápisu. Velmi často se u něj můžeme setkat také s metodou opakovaného výzkumu, který je pro přesný záznam velmi důležitý. Velkou pozornost věnoval i samotnému výběru zpěváků, kteří měli větší písňovou zásobu. Tyto zpěváky potom opakovaně navštěvoval jednak proto, aby jejich repertoár zcela vyčerpal, a jednak proto, aby si ověřil, že repertoár reprodukují stále stejným způsobem. ${ }^{23}$

15 Více ŠTĚDROŇ, Miloš. Janáčkovy poznámky k frankfurtskému festivalu. Opus musicum 3 , 1991, s. 8-10.

16 JANÁČEK - VÁŠA, op. cit.

17 VETTERL, Karel. Lidové písně a tance z Valašskokloboucka. 1, 2. Praha: ČSAV, 1955, 1960.

18 BÍM, Hynek. Lidové písně z Hustopečska. Praha: Orbis, 1950. 150 s. Viz. též nové vydání BÍM, Hynek. Lidové písně z hanáckého Slovácka. Jiří Vysloužil (ed.). Klobouky u Brna: Městský úřad, 1998.

19 BÍM, Hynek. Valašské a Slovenské lidové písně. Praha: SNKLHU, 1954.

20 BÍM, Hynek. Zpěvník národních písní. Praha: Nakladatelství Československé obce sokolské, 1946.

21 BÍM, Hynek. Slovenské národné piesne. Praha: ČOS, 1947.

22 Číselné údaje převzaty z článku VETTERL, Karel. Nad dílem Hynka Bíma. Český lid 46, 1959, s. 177.

23 Více o výběru interpretů VYSLOUŽIL, op. cit., s. 51-55. 
Pomocí těchto metod Bím také dokázal, že je nutné opětovně navštěvovat oblasti, ve kterých již sběr jednou probíhal. $V$ jeho záznamech se můžeme setkat s pokusy mapovat jeden kraj a se snahami zachytit co nejvíce variant jedné písně, tak jak si ji předávali jednotliví zpěváci či jednotlivé kraje mezi sebou. Problém záznamu jednotlivých hodnot přeměroval pomocí telegrafního klíče na pásce. Měření probíhalo tak, že vyt'ukával na pásku délky tónů a následně je měřil. ${ }^{24}$ Pomocí klíče určil přesnou délku tónů, čímž docílil co nejpřesnějšího záznamu. Na rozdíl od jiných sběratelů se nesnažil melodie lidových písní násilně vměstnat do jednotlivých pravidelných taktů, ale ponechal zápisu volnost, a tím i lepší představu o vlastní podobě písně. S čím se ale $\mathrm{v}$ jeho zápisech často setkáváme, je záznam jedné písně různými způsoby tak, aby text nebyl roztrhán a př́izvuk byl dodržen. ,, Bím studoval a zapisoval skutečně živou píseň a ne pouze text a základni melodické a rytmické obrysy lidové písně, jak bylo v této době zvykem. "25 Tyto Bímovy snahy také demonstruje fakt, že zápisem nápěvu a textu jeho sběratelská práce nekončí. Pokud to bylo možné, prripojoval informace o interpretovi a prostředí. Pomocí přesného záznamu a popisu prostředí se staly Bímem zapsané písně samostatným a plnohodnotným pramenem, který můžeme využít pro bádání v oblasti lidového zpěvu.

\section{2. „Kostelní písně ze Znorov“}

\section{Obsah jednotlivých sběrů kostelních písní z Vnorov}

Kostelní písně ze Znorov, zapsány Bímem 17. záríi 1911:

1. Andělové, andělové sú zpivali

2. Co to slyším za líbi hlas Marie

3. Jestlit psáno dávným rokem

4. Maria, dej dovolení

5. Maria pod kř́žem stála

6. Otče náš nebeský $k$ tobě voláme

7. Prorokovali proroci

8. Roráte coeli, Když svatí proroci

9. S pastýri pospichejte, krestané k Betlému

10. Toto malé détátko

11. Tř krále znamenali hvězdu

12. Vždycky se sluši modliti

13. Zas nová radost nastala

14. Z hvězdy vyšlo slunce

24 ÚLEHLA, Vladimír. Živá píseň. Praha: F. Borový, 1949, s. 165.

25 VYSLOUŽIL, op. cit., s. 53. 
Kostelní písně ze Znorov, zapsány Bímem 24. září 1911:

1. Bože Abrahámu, králi Pane pánú

2. Den přeslavný jest $k$ nám přišel

3. Ej, Zacheus muž nevelký

4. Když ochrany nejvyššiho v skřejšich je uživá

5. Nastal nám čas velmi veselý

6. Otče náš milý pane

7. Pán Bůh jest sila má

8. Pokoj, zdravi požehnáni stañ se v tomto domu

9. Poslúchejte kŕetané co se jest stalo

10. Poslúchejte křetané co se jest stalo

11. Utěšený nám den nastal

12. Veselé vánoční hody

13. Všickni lidé, kteři spite

14. Zvěstujem vám radost převelmi veliků

Kostelní písně ze Znorov, zapsány Bímem 1. října 1911:

1. Dyž byl Pán Ježíš pochován

2. $\quad$ Narodilo se dètátko

3. Nebeský pán aby dokázal nám

4. Ó, dobrú noc, Bože věčný

5. Pozdravená budiž lilium vonné, svatá Anno

6. $\quad$ Přeušlechtilé manželstvo hned v ráji ščípeno

7. Slyšte hlas Panny Marie

8. Veliká to milost'Boha Otce byla

9. Vši čistoty nejkrásnějši kvitku

10. Zas dnešni den pominul

Ačkoli tvoří soubor starých kostelních písni ${ }^{27}$ jen nepatrnou část $\mathrm{z}$ celkového počtu Bímem zaznamenaných písní, sám Bím mu věnoval značnou pozornost. O tom svědčí i množství dopisů, ve kterých se tímto tématem zabývá ve vzájemné korespondenci s Leošem Janáčkem. ${ }^{28}$ Tento výběr písní může sloužit jako reprezentativní vzorek aktivně zpívaných duchovních písní v této oblasti a podle četnosti změn v melodickém či textovém základu oproti výše zmíněnému kancionálu nám také může ukázat míru zpěvákovy invence. Jak již upozorňoval Otakar Hostinský v souvislosti se studiem světských písní pocházejících z 16. století: „,Ačkoliv prohledal jsem dosud větši toliko část hymnologického materiálu,

26 Tato píseň je ve stejném znění zapsána Bímem dvakrát.

27 Termín „kostelní písně“ je běžně užíván paralelně s termíny „,duchovni““ či „lidová duchovní píseň“. Jedná se tedy o všechny primárně notované i nenotované písně náboženského charakteru, které byly sdružovány ve zpěvnících (kancionálech). Více k terminologii MALURA, Jan. Písně pobělohorských exulantũ. Praha: Academia, 2010, s. 54-74.

28 Celkem je kostelním písním z Vnorov věnováno šestnáct dopisů. 


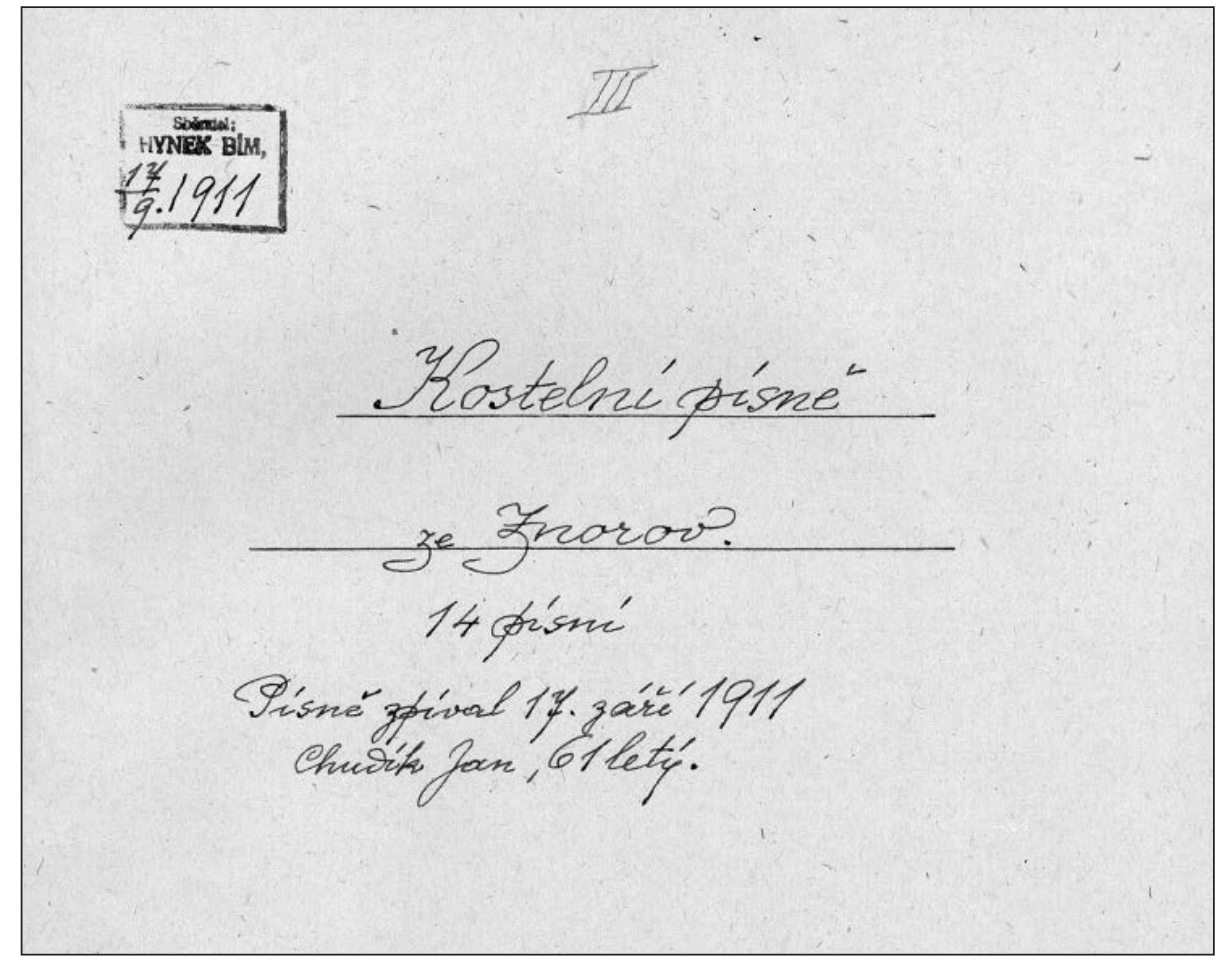

Př. 1 Titulní list sběru ze dne 17. září 1911. Uloženo v EÚ AV ČR v Brně, A 1084.
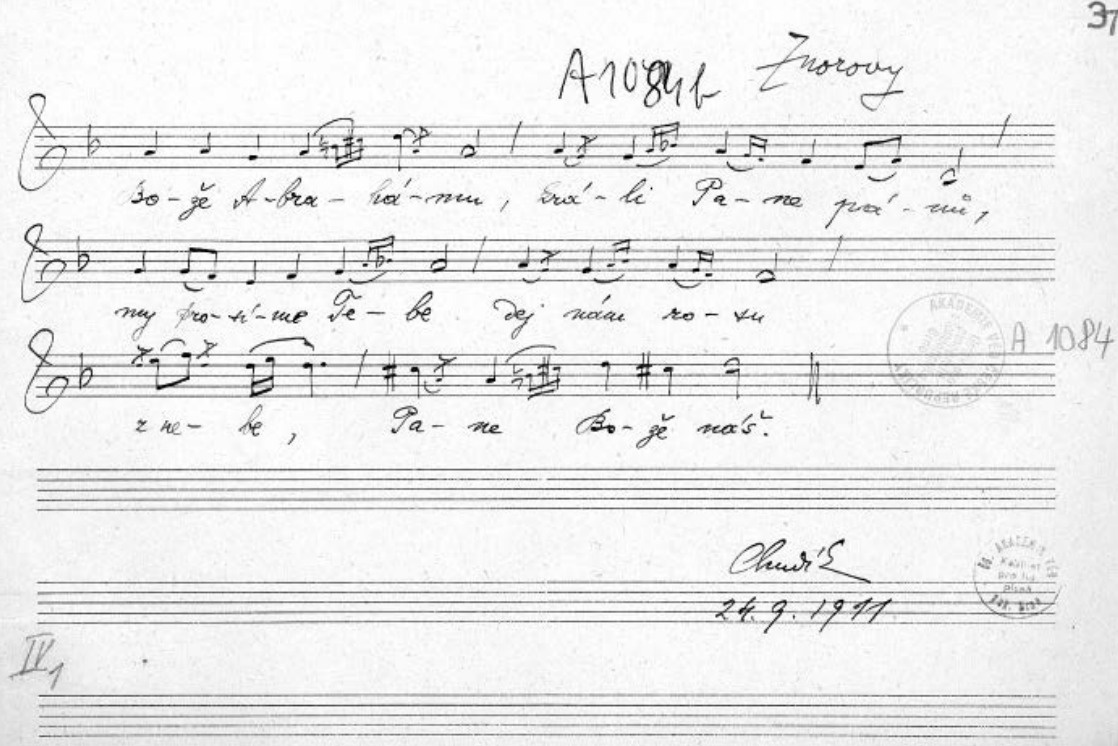

Př. 2 Bože Abrahámu, králi Pane pánú. Uloženo v EÚ EV ČR v Brně, A 1084. 
z něhož nápěvy lidové možno čerpati, přece i těchto 36 nápěvech písňových smíme spatřvati jakousi povolanou reprezentaci, podle které možno již posuzovati celkový stav lidového zpěvu. "29

To, že šlo o repertoár, který byl v tomto prostředí pevně zakořeněný, nám naznačuje i samotná Bímova předmluva ke kostelním písním. Zde se zmiňuje, že tamní faráŕ František Zmeškal zakázal zpěvákủm zpívat písně: ,,[...] starověrské z kancionálu Slaviček rajský (od Bočana). Kancionál jim odebral a zpěváci zpívali písně jinými melodiemi, než jsou ve jmenovaném kancionálu. "30 Tento zákaz měl dokonce takový dopad, že Janáček sám vznesl požadavek na biskupství v Brně a žádal jeho zrušení. Dále Bím cituje Janáčkův dopis z 28. srpna 1911, kde projevuje přání pořídit fonografický záznam těchto písní a tím přesvědčit kanovníka Geislera ${ }^{31}$ a biskupa Weisnara ${ }^{32}$ o výjimečnosti těchto nápěvů. ,,[...] tím živým dokladem chci přesvědčit kan. Geislera a bisk. Weisnera, že nerozumné je takový poklad zakopávat. "33 Samotný fonografický záznam byl pořízen ještě $\mathrm{v}$ zář́ téhož roku. ${ }^{34} \mathrm{Na}$ tomto místě je také nutné zmínit i Janáčkovu provázanost s prostředím a znalost obce Vnorovy a jejího blízkého okolí. Byly to právě Vnorovy, kde našel Janáček po předčasné smrti otce roku 1866 útočiště u svého strýce Jana Janáčka, který zde působil jako farář mezi léty 1870 až 1878. Je tedy jisté, že se Leoš Janáček seznámil s kancionálem v dobách, kdy sám hrál na vnorovském kůru na varhany. Janáčkova poslední návštěva zde se uskutečnila roku 1927. ${ }^{35}$

Dř́ve než byl záznam pořízen, zapsal Bím sedmnáct nábožných písní, jak mu je zazpíval gajdoš Martin Babulík, a odeslal je Janáčkovi už v roce $1907 .{ }^{36}$ To, že Janáčka i Bíma vnorovské nábožné písně zaujaly, dokazuje dopis z 28. června 1907: , ,Tak kupř. do Znorov a Lideřrovic vykonal jsem již 11 cest a ještě nejsem hotov ani s písněmi světskými. A začíná mně tam znovu práce nová: písně kostelní, které jsou velmi pozoruhodné. " Textové incipity sedmnácti kostelních písní, které zde Bím pořídil, sepsal v dopise L. Janáčkovi z 27. záŕí 1911. ${ }^{37} \mathrm{~S}$ prvním

29 HOSTINSKÝ, Otakar. 36 nápěvů světských písní českého lidu XVI. století. Praha: Státní nakladatelství krásné literatury, hudby a umění, 1957, s. 8.

30 EÚ AVČR, Brno - Kostelní písně ze Znorov: Bímova předmluva ke vnorovskím kostelním pisnim, sign. A1084, s. 6.

31 Jindřich Geisler působil jako kaplan ve Vyškově a jako kanovník a vikář v Olomouci. Mezi léty 1912-1916 byl členem Jednoty pro zvelebení církevní hudby na Moravě.

32 Ačkoli je v dopise z 28. srpna 1911 i v předmluvě k zaznamenaným kostelním melodiím uvedeno jméno Weisnar, přikláním se k názoru Dany Toncrové (op. cit.), že se jedná o Karla Visnara, světícího biskupa v Olomouci.

33 Bímova předmluva ke Kostelním písním ze Znorov, op. cit., fol.1.

34 Některé z nich k dispozici na CD k publikaci: Kol. autorů. Nejstarši zvukové záznamy moravského a slovenského lidového zpěvu (z folkloristické činnosti Leoše Janáčka a jeho spolupracovnikui). Brno: Gnosis, 1998.

35 DVORSKÝ, op. cit., s. 19.

36 Dopis z 28. září 1911. V seznamu kostelních písní ale uvádí sám Bím, že sedmnáct písní zapsal roku 1906 a na jaře roku 1907 zaznamenal pouze jednu nábožnou píseň.

37 Jednalo se o tyto písně: Když za císaře Neróna; Já neščasný na tom světě; Jazyk nemuž vyslo- 
sběrem mu zde pomáhal student strážnického gymnázia František Kůrečka, jehož zápisy ale obsahovaly četné chyby, které musel Bím následně opravovat. Jak také vyplývá z Janáčkova dopisu Bímovi z 30. ledna. 1907, ,,[...] p. František Kůrečka, studující VII. tř́dy, c. k. gymnázia ve Strážnici má dobrou vůli, ale neumí notovat [...]. "38 Další, kdo se na sběrech podílel, byl vnorovský učitel Martin Prášek. Od něho však Bím získal texty převážně světských pisni. ${ }^{39}$

O záměru sesbírat více kostelních písní, které se ve Vnorovech udržují, informoval Bím Janáčka v dopise z 12. prosince $1909 .{ }^{40} \mathrm{O}$ dalších dvaceti osmi zápisech kostelních písní se ale Bím zmiňuje až 27. září 1911. Ve stejném dopise také informuje, že by bylo nejlepší nahrát písně ve Vnorovech 15. října 1911. Sám Janáček se nahrávání kvưli pracovnímu vytížení účastnit nemohl. Pouze instruoval Bíma $\mathrm{v}$ dopise $\mathrm{z} 11$. října $1911^{41} \mathrm{k}$ tomu, aby od každé písně natočil dva až tři verše. Nahrávání se málem ve smluvenou dobu nakonec neuskutečnilo, protože nedošly včas objednané válce do fonografu, které s sebou měla dovézt Františka Kyselková. Podle Janáčkova telegramu ze 14. října 1911 však víme, že válce nakonec dorazily včas a nahrávání probíhalo od 15. ř́ijna do 20. října 1911. Písně byly zpívány Tomášem Kůsalíkem z Lideřovic a tamními manželi Chudíkovými, písně kostelní interpretoval potom sám Jan Chudík. O průběhu nahrávání hovoř́i až dopis Bíma Janáčkovi z 20. ř́ijna 1911. ${ }^{42}$ Vyvstal zde pouze jeden problém, Janáček neodeslal Bímovy texty již dříve zaznamenaných sedmnácti písní od Martina Babulíka a zpěváci je nemohli zazpívat pro fonograf, protože neznali celé sloky.

20. ř́ijna 1911 zemřel vnorovský farář František Zmeškal, který zakázal zpívat písně z kancionálu Slaviček rajský. Fakt, že kancionál nebyl nijak masově rozšířen mimo region i to, že se s ním Bím do té doby nesetkal, potvrzuje také jeho požadavek: „Přemýšlím také, nebylo-li by možno tento kancionál (pocházi z roku 1719) vydat tiskem aspoň ve výběru nejlepšich pisni a obnovit ho tak na Slovácku, kdež je zakořeněn. "43 Janáček na tuto myšlenku reaguje v dopise z 18. ledna 1912 „Kancionál opisovat netřeba; exemplárù jeho je všude dost. "44 Pouze dodává, že ,, [...] dobře, když by ho dal p. exministrator do kostela “ ${ }^{45}$ Bím

vit; Jéžiši, chleba anjelský; Márnost nad márnosti sú lidské starosti; Můj milý člověče, bliži se k svitáni; Na bubny trúby píštaly; O přesvatá Trojice Otče, Synu, Duchu svatý; Povstan̆, člověče, z hř́chu; Pod tvuj plášč se utíkáme; Prozpěvujtež všickni; Slávo markrabství tohoto; Vitej milý Jezu Kriste; Vy krásni serafinové; Zdráv bud' náš Stvořiteli; Zdrávas královno růžence. Viz TONCROVÁ, op. cit., s. 116.

Ibid., s. 52.

Podle dopisu z 11. prosince 1910 mu Martin Prášek poskytl 125 textı̊ písní. Ibid., s. 96.

Ibid., s. 81.

Ibid., s. 118.

Ibid., s. 120 .

Ibid.

Ibid, s. 124.

Ibid. 
tedy alespoň zapůjčil a provedl srovnání textů a ve Vnorovech zaznamenaných melodií. Podrobnější výsledky této komparace však nejsou zaznamenány.

Celá korespondence, zabývající se Vnorovami a kostelními písněmi, končí dopisem Janáčka Bímovi z 18. ledna 1912. Zde Janáček, stejně jako v dopise z 28. srpna 1911, slibuje, že pustí vnorovské nahrávky kostelních písní Františku Ehrmannovi ${ }^{46}$ a Jindřichu Geislerovi, ,[...] aby viděli, co se z Olomouce zakázalo, a co třeba napravit". ${ }^{47}$

\section{Kancionál Slavíček rájský}

Již bylo upozorněno na fakt, že kancionál Slavíček rájský Jana Josefa Božana silně ovlivnil povědomí místních obyvatel v oblasti duchovních písní. Je známo, že byl roku 1719 v Hradci Králové u Václava Jana Tybeliho vytištěn velký počet exemplárů a jeho vlastnictví nebylo tedy až takovou výjimkou. Důkazem nám může být také to, že hrabě F. A. Špork, který celý náklad financoval „[...] rozdával Božanova Slavička zdarma českým farám, školám a také mezi lid, takže v roce 1736 už byl celý, dosti značný, náklad vyčerpán. " ${ }^{8} 8$ Nelze si však představovat, že by byl kancionál masově rozšířen mezi lidem a patřil k běžně dostupným. Byl oficiálně doporučen konzistoří a i podle dnes dochovaných exemplárư můžeme říci, že většina výtisků byla ve vlastnictví farních knihoven a kůrů. Lid se pak $\mathrm{s}$ jeho obsahem seznamoval až díky zpěvům v kostele.

Ačkoli je jméno Jana Josefa Božana s kancionálem spojováno, nelze ho považovat i za autora všech zde obsažených písní. Však také sám v předmluvě udává: „Co v této knižce se nachází, nic mého není, mimo spořádáni věci odjinud porozdilně sebraných a dílem z latiny $v$ češtinu uvedených [...].““99 Jak bylo již dáno dobovou praxí, byl především upravovatelem již starších nápěvů a textů, ze kterých kancionál vznikl jejich následnou kompilací. Výsledkem tedy bylo, že kancionály byly tvořeny $\mathrm{z}$ velké části dříve vytvořenými kontrafakty. Obecně jsou kontrafakta chápána jako duchovní písně vzniklé novým otextováním již dříve známého nápěvu. Prvním, méně početným typem, jsou kontrafakta, která již známý nápěv uvádí př́imo opatřený novým textem. Druhým typem kontrafakt je prípad, kdy je uveden jen nový text s odkazem na př́slušnou melodii. Poměrně častým jevem u kontrafakt je př́ípad, kdy ve všeobecnou známost vešel nový tvar písně a starý text přešel k odkazové praxi. Tvorba a výskyt kontrapozit, použití starého textu pro nově vytvořenou melodii, byl jev již méně častý. Nové texty byly tvořeny hlavně na dobově oblíbené nápěvy, mnohdy se jednalo i o nápěvy světské. Tyto nápěvy byly upřednostňovány z toho důvodu, aby se nové texty co

\footnotetext{
46 Franišek Ehrmann působil jako prelát a kanovník v Olomouci a mezi léty 1912-1916 byl členem Jednoty pro zvelebení církevní hudby na Moravě.

47 Ibid., s. 124.

48 KOSEK - MALURA, op. cit., s. 35.

49 Slaviček rájský, s. 3.
} 
nejrychleji adaptovaly a vepsaly do povědomí lidu. I Slaviček rájský přebírá tento velmi rozšířený způsob odkazové praxe. Před vypisováním nápěvů či notových incipitů písní je mnohdy dávána přednost odkazu na „,notu obecni'“. V takovém prŕṕpadě mohla být pro interpretaci použita každá melodie, na kterou se mohla interpretovat sloka o čtyřech osmislabičných verších, tzv. carmina jambica dimetra. Mezi tradiční okruh odkazů patř́ také odkazy ve tvaru ,má svou notu“, „, vlastni nota “, „nota zvláštni “ nebo prostě jen „zpivej jako“. Jedná se o písně, které byly obecně známé a nebylo jim třeba priř̌azovat odkaz nebo vypisovat jejich melodii. ${ }^{50}$

Asi největší Božanovým zdrojem byla Capella regia musicalis Václava Karla Holana Rovenského z roku 1693. Několik duchovních písní je také převzato z Jesliček Fridricha Briedla z roku 1658, Adama Michny z Otradovic, z Kancionálu Jana Rozenpluta z roku 1601 a z Pisni historických Šimona Lomnického z Budče z roku 1595. Mimo těchto barokních zdrojů se ale Božan obracel i na tvorbu z období středověku. Středověká vrstva kancionálu je zde zastoupena písněmi jako např́klad Hospodine pomiluj ny ${ }^{51}$, Vitej milý Jezu Kriste ${ }^{52}$ a piseň oslavujicí kult sv. Václava Svatý Václave, vévodo české země ${ }^{53}$. Mimo primárně katolický repertoár byly Božanem zařazeny $\mathrm{v}$ menší míre i písně utrakvistické provenience a z produkce jednoty bratrské. ${ }^{54}$ Božan sestavil kancionál na základě své pastorační praxe venkovského faráře a odráží tedy i samotnou praxi venkovských farností.

Specifikem kancionálu je i jeho orientace na Moravu a její významná poutní místa. Můžeme zde nalézt texty písně oslavující Pannu Marii Tuřanskou či Křtinskou. Tyto písně poutního charakteru jsou tvořeny jednoduchým, lehce zapamatovatelným veršovaným textem a jednoduchou melodií, tak aby si lid text velmi brzy osvojil. Navíc jsou všechny písně, vícehlasé i jednohlasé s generálbasovým doprovodem, notovány na samostatné osnově a pro lepší orientaci zpěváka je uveden kustod na každém konci řádku. K záznamu melodie je použito černo-bílé menzurální notace. S výjimkou užití starých klíčủ, kustodů a znaku pro notu brevis, který je pozůstatkem z předchozí menzury, je notový zápis dobře čitelný a použitelný v praxi i o celých dvě stě let později. Díky výzkumu hudebních archivů při českých chrámových kůrech v 60 . letech 20. století, bylo zjištěno, že mezi v praxi nejužívanější hudebniny na území českých zemí patřil mimo Šteyerova Kancionálu českého a kancionálu Capella regia musicalis V. K. Holana Rovenského také Božanův Slaviček rájskź. ${ }^{55}$

50 Více o složení kancionálů a principu šíření nápěvů SMÉKALOVÁ, Kateřina. České kancionály 1. poloviny 16. století. Techniky a typy redakčnich úprav jejich obsahů. Diplomová práce. Brno: Masarykova univerzita. Filozofická fakulta. Ústav hudební vědy, 2009. Slaviček rájský, s. 626, č. 715.

52 Ibid., s. 341, č. 375 .

53 Ibid., s. 619, č. 773 .

54 Více o složení Slavička rájského KOSEK - MALURA, op. cit.

55 ŠKARPOVÁ, Marie. Kancionál český M. V. Šteyera - návrh českého hymnografického ká- 
Hlavní důvod, proč byl Slaviček rájský tak oblíben, je pak zcela nasnadě. Vůbec nejrozsáhlejš́ část kancionálu je oddíl 823 českých duchovních písní. Písně, které př́mo nereprodukovaly biblická témata či nevysvětlovaly konkrétní události popsané v Písmu, se vázaly na události v životě křest’ana a obyčeje, jako například Vánoce či Velikonoce, které byly udržovány nehledě na konfesní př́slušnost a přežívaly mezi lidem nejdéle.

To, jak se Božanův kancionál do Vnorov dostal, se nám zřejmě dnes již zjistit nepodaří. Lze však předpokládat, že se do Vnorov dostal ihned po svém vydání 1719, za působení tehdejšího faráře Jana Františka Josefa Trtiny. ,Trtina je postava mimořádná. V době jeho působeni vybudovali Želečtí ve Veseli servitský klášter s kostelem svatých Andělů stráżných. Děkan Trtina se snažil držet se servity krok a tak jeho působení zahajuje dobu barokního a kulturního vzestupu celého Veselska. "56 Kancionál mohl tedy poř́́dit právě Trtina, který se snažil Vnorovy udržet v centru pozornosti. I když Vnorovy patřily spolu s Lidéřovicemi a Zarazicemi pod správu veselské farnosti, byl v zájmu upevnění katolicismu rozšířen kancionál i do Vnorov. Vždyt' právě zde bylo roku 1731 zřízeno lokální kaplanství.

\section{Funkční určení, původ a srovnání písní s kancionálem}

Zaměření jednotlivých písní vychází jednoznačně z textu a má tedy př́mou vazbou na církevní rok. Podle určení byly Bímem zaznamenány písně adventní, vánoční, postní, velikonoční, $\mathrm{k}$ oslavě svatých a písně vážící se svým obsahem $\mathrm{k}$ událostem v životě křest’ana. Nejvíce písní tohoto souboru pochází z vánočního okruhu, nachází se zde dvanáct písní vánočních a tři písně adventní. Sedm písní je určeno pro velikonoční čas a postní období, dvě písně jsou označeny jako poutní, tři písně $\mathrm{k}$ úctě svatým a jedna svatební, dále skupina čtyř písní, z nichž jsou některé Bímem označeny jako Posvěceni chrámu. Tyto písně jsou určeny k př́ležitosti hodů. Dvě písně pocházejí z oddílu $V$ čas sucha, který byl běžnou součástí všech kancionálů a má funkci př́ímluvy za dobrou úrodu. Př́ímo k bohoslužbě se potom váží dvě písně večerní a jedna, jež byla zařazována před kázání.

Zde je nutné upozornit na fakt, že zdaleka ne všechny duchovní písně, které Bím zaznamenal, se nacházejí v kancionálu Slaviček rájský. Celkem lze podle shodných textových incipitů dohledat v kancionálu dvacet tři písní. Badatelskou práci poněkud komplikuje záznam pouze první sloky každé písně, taktéž textové varianty písní v Bímových zápisech nejsou zaznačeny. Melodické varianty jsou zapsány pouze, pokud je možná dvojí interpretace melodických ozdob či průchodných tónů.

попи. Diplomová práce. Brno: Masarykova univerzita. Filozofická fakulta. Ústav české literatury a knihovnictví, 2006, s. 20.

56 JELÍNEK, Josef - MOTYČKA, Tarzicius Martin. Duchovni a historické dědictví farnosti svaté Alžběty Durynské ve Vnorovech. Vnorovy: Římskokatolická farnost, 2009, s. 55. 
Z celkového počtu třiceti šesti kostelních písní z Vnorov se jich dvacet tři nachází i ve Slavićku rájském a osm z nich vychází z kancionálu i melodicky. Nejvíce písní shodných s kancionálem je učeno pro Vánoce a Advent. Ze třinácti písní nacházejících se $\mathrm{v}$ tomto oddíle je jich deset obsaženo i kancionálu a pět $\mathrm{z}$ nich nese výrazné znaky nápěvu zaznamenaného v kancionálu (Den přeslavný jest k nám přišel; Narodilo se jest dètátko; Prorokovali proroci; Veselé vánočni hody; Zvěstujeme vám radost převelikư). ${ }^{57}$ Koleda Poslúchejte, krest'ané, co se jest stalo není sice zaznamenána $\mathrm{v}$ kancionálu, ale s menšími melodickými obměnami je zařazena do druhé i třetí Bartošovy sbírky. ${ }^{58}$ Oproti tomu duchovní píseň Maria, dej dovolení se v kancionálu nevyskytuje, ale shodná textová i melodická varianta se nachází např̀ v kancionálu Capella regia musicalis (1693/94) Václava Karla Holana Rovenského. Ze sedmi písní z velikonočního a postního okruhu se v kancionálu nachází pět písní (Dyž byl Pán Ježíš pochován; Jestlit' psáno dávným rokem; Maria pod kř́žem stála; Nebeský pán aby dokázal nám; Utěšený nám den nastal), z nichž pouze dvě (Jestlit' psáno dávným rokem; Maria pod kř́žem stála) byly převzaty ve Vnorovech. Píseň Ó, dobrú noc, Bože věčný se sice v kancionálu nevyskytuje, ale byla zaznamenána s mírnými melodicko-rytmickými obměnami v obci Velká. ${ }^{59}$ Bím určuje zpěv této písně na Velký pátek a zajímavý je taktéž Bímův vpisek na konec písně „Tato píseň zpívá se mnoho v Polsku"60

$\mathrm{Z}$ okruhu písní za úrodu se $\mathrm{v}$ kancionálu nachází pouze píseň $\mathrm{s}$ textovým incipitem Bože Abrahámu, králi Pane pánů. Ačkoli sám Bím píseň neoznačil jako Za déšt', můžeme s určitostí tvrdit, že byla píseň pro tyto účely užívána. Mimo Slavíčka rájského se jako Za déśt' se objevuje již ve Vodňanském kancionálu z roku 1537. Díky tomuto kancionálu můžeme také zjistit, že se jedná o kontrafaktum, které přebírá již dřive známý latinský pašijový nápěv Deus omnipotentens a morte resurgens (Bůh všemohoucí, vstal z mrtvých žádoucí). Latinskou verzi můžeme doložit již v Jistebnickém kancionálu. ${ }^{61}$ Jednotlivé zde uvedené varianty jsou vzájemně odlišné. Nejvíce společných znaků můžeme nalézt v prvním hlasu Božanova kancionálu a vnorovském zápisu. Bím zaznamenal nápěv shodný s variantami, které se nacházejí v Bartošových sbě-

Podrobnější rozbor melodické a textové složky písní viz SMÉKALOVÁ, Kateřina, op. cit.

BARTOŠ, František. Národni písně moravské v nově nasbirané. Brno: Matice moravská, 1889, s. 531. BARTOŠ, František - JANÁČEK, Leoš. Národni písně moravské v nově nasbirané. Praha: Česká akademie císaře Františka Josefa pro vědy, slovesnost a umění, 18991901, s. 1015.

BARTOŠ - JANÁČEK, op. cit., s. 1101.

Pro nedostupnost starších pramenů polské provenience ale nyní nelze toto tvrzení poprrít ani vyvrátit.

Výše zmíněná česká kontrafakta se běžně nachází v kancionálech pořízených literátskými bratrstvy, jako je např́klad Chrudimský kancionál z roku 1530, Kolinský kancionál z roku 1517 a Poličský kancionál z roku 1545. Dále je můžeme nalézt v bratrských kancionálech z let 1541 a 1564 a v neposlední řadě také v kancionálu Závorky Lipenského. Textově je varianta shodná s Poličským kancionálem. 
rech. ${ }^{62} \mathrm{Je}$ tedy velmi pravděpodobné, že varianta zapsaná Bímem byla v lidovém prostředí obecně rozšířena. Bez vazeb na starší prameny a Bartošovy sbírky je píseň Otče náš nebeský k tobě voláme. Všechny tři zápisy písní určeny pro př́ležitost hodů (Ej, Zacheus muž nevelký; Pokoj, zdraví požehnání staň se v tomto domu; Všickni lidé, kteří spíte) se v kancionálu nachází. Jejich nápěv je ale zcela odlišný. Protože nebyly Bartošem zaznamenány a v pramenech předcházejících Slavićku rájskému nebyly nalezeny, je možné, že pro původní text byl použit nápěv, který měl v této lokalitě již pevnou tradici. Stejný případ je i v oddíle písní obecných. Pouze u písně Pán Bůh jest sila má se nápěv z kancionálu adaptoval s melodickými obměnami v lidovém prostředí. Zajímavá je píseň $\mathrm{s}$ textovým incipitem Přeušlechtilé manželstvo hned v ráji štípeno, která byla také obecně rozšířena v lidovém prostředí. Důkazem nám může být její zachycení lidovým písničkářem Štěpánem Losem v Řeporyjích u Prahy. ${ }^{63}$ Skupina písní oslavující svaté (Pozdravená budiž lilium vonné, svatá Anno; Vší čistoty nejkrásnější kvít$k u$ ) a písní určených k pouti (Vší čistoty nejkrásnější kvítku; Co to slyším za líbý hlas Marie; Slyšte hlas Panny Marie; Zas nová radost nastala) se ve Slavícku rájském a ve starších pramenech nenachází. Okruh těchto poutnických písní bez výjimky oslavuje mariánský kult. Avšak pouze s písní Slyšte hlas Panny Marie se můžeme setkat jak v druhé Bartošové sbírce ${ }^{64}$, tak i v kancionálu Salve regina, poutnický kancionál pro poutě a laické pobožnosti ${ }^{65}$, velmi pravděpodobná je však jejich přejímka z kramářských tiskü. Stejně tak písně k poctě svatých, v našem príípadě k sv. Anně a k sv. Josefu, byly spíše regionální záležitostí a nebyly tedy součástí kancionáli̊, které přesahovaly lokální charakter.

Výrazná shoda mezi duchovními písněmi z Vnorov a kancionálem Slavíček rájský je př́edevším $\mathrm{v}$ jejich textové složce. Ve všech případech je textová varianta vnorovských sběru zcela shodná s kancionálem. Pokud zde nastane jistá obměna, týká se zpravidla pouze jednoho slova nebo je užit jeho nářeční tvar. Ve Vnorovech patř́i mezi nejčastější změny dloužení samohlásek podle nově kodifikovaných jazykových norem (např. narozeni $\rightarrow$ narození) a odstraňování starší varianty slova (např. vzejdet' $\rightarrow$ vzejde, židův $\rightarrow$ židü, Abrahámuv $\rightarrow$ Abrahámu). Dalším jevem je přeměna tvarů slov ze spisovné češtiny do jejich podoby nářeční $(k d y \check{z} \rightarrow d y \check{z}$, panenskou $\rightarrow$ panenskú, velikou $\rightarrow$ velikú).

Nápěvná složka písně je však v mnoha případech zcela odlišná. Pokud se stejná píseň nalézá i v některé $\mathrm{z}$ Bartošových sbírek, nacházíme zde shodu v nápěvné složce písní. Textová složka duchovních písní z Velké se odlišuje pak především nářečně. Vnitřní struktura písní je ve většině případů respektována tak, jak je dána Slavíckem rájským. To, že se zachovává struktura, je ale spíše dáno ustále-

62 BARTOŠ, op. cit. 608. BARTOŠ - JANÁČEK, op. cit., s. 1109.

63 ZÍBRT, Čeněk. J. S. Baar, farář ořechovský, na svatbě v Řeporyjích u Prahy. Český lid, 26, 1907, s. 140-148.

64 BARTOŠ, op. cit., s. 1094.

65 MALÝ, František. Salve regina, poutnický kancionál pro poutě a laické pobožnosti, Brno: Salve, 1992. 
ným způsobem zpěvní artikulace, která je podřízena provozování písní v kostele či při jiných př́ležitostech a odpovídá celkové tradici. Velmi často se tedy můžeme setkat se sekvenční stavbou písní, u nichž je struktura vždy zachovávána.

Jednotlivé varianty písně nám dávají také poznat míru modifikace nápěvné a textové složky a způsob změn, které se projevují při přenášení kostelních nápěvů do lidového prostředí. Je však nutné opět připomenout, že i repertoár Slavička rájského má základ v kancionálech sahajících až do počátku 16. století. Celkem můžeme nalézt i ve vnorovské sbírce šestnáct takovýchto písní, které migrovaly mezi kancionály bez ohledu na lokalitu vzniku a užití kancionálu. Tyto duchovní písně, které jsou do kancionálů opakovaně zařazovány, také vykazují stejné znaky v přenášení písní z kancionálu do kancionálu jako pozdější zápisy těchto duchovních písní v lidovém prostředí. Textová složka je tedy s menšími obměnami zachovávána, $\mathrm{v}$ př́padě kancionálů také přizpůsobována konfesijním požadavkủm. V lidovém prostř̌edí se ve větší míře můžeme setkat se zásahy do melodické složky písně. Právě v melodické složce duchovních písní z Vnorov můžeme sledovat regionální vlivy, které byly vnášeny do nápěvu písně.

Velmi důležitou roli v poznání melodické struktury písně a její odlišení od ostatních variant reflektují Bímovy záznamy melodických ozdob. To, co spojuje melodiku písní nehledě na jejich funkční určení a dává písni typický ráz, jsou melodické ozdoby. Jak je také zřejmé z Bímových zápisů, nejsou tyto ozdoby fixně dané, nýbrž závisí z části na interpretovi. Již Úlehla zdůrazňuje roli př́ikrasných tónů, melodických ozdob, v souvislosti s písní na Strážnicku: „Mnohá př́značnost najde se též $v$ tónech přikrasných, jimiž se tóny nápěvné obaluji, spojuji a uzavíraji. Jejich bohatost sama odlišuje strážnickou písen̆ pospolu se vši písní jihovýchodní výspy od pisně typu západniho, kde přikrasné tóny skoro chybějil. " ${ }^{66}$ Tyto prŕíkrasné tóny nelze ale chápat jako něco, co tvoří sám zpěvák bez ohledu na tradiční znění písně. Při srovnávání jsme si mohli povšimnout, že i tyto melodické ozdoby zachovávají určitou ustálenou strukturu, která svědčí o tom, že byly ve Vnorovech tyto príkrasné tóny zakonzervovány a jednotlivými interprety opakovány. Zvláště typické je zde použití spodní velké sekundy, jak $\mathrm{v}$ prríkrasných tónech, tak $\mathrm{v}$ tónech hlavních. Velmi často je užita také průchodná kvinta a kvarta. Právě v tom vidí např. Josef Černík typické hudební znaky celého Slovácka.$^{67}$ Dalším faktorem, který mohl ovlivnit zásahy do nápěvné složky písní, byla nástrojová hudba. $Z$ písní, které by mohly být takto ovlivněny, můžeme uvést např́klad píseň Zvěstujeme vám radost převelikú. Zde je téměř každý hlavní tón obalen množstvím melodických ozdob v sekundových krocích.

Přesto se však písně svým charakterem nevymaňují ze starých církevních tónin, ale dodržují původní stavbu a základ. Nápěvné varianty duchovních písní, které Bím zaznamenal ve Vnorovech, jsou tedy kompilací původního nápěvu, regionálních vlivů a vlastní invencí interpreta. Je ale také nutno zdůraznit, že jsou

66 ÚLEHLA, op. cit., s. 280.

67 ČERNÍK, Josef. Umění hudební. Moravské Slovensko. Sv. 2. In Národopis lidu českoslovanského. Díl 1. Praha: Národopisné muzeum českoslovanské, 1922, s. 618. 
to právě zásahy do textové a nápěvné složky písně, které nám dokazují, že byly písně mezi lidem rozšiřrené. Také proto můžeme celkem dvanáct písní dohledat i v Bartošových sbírkách. ${ }^{68}$

Jak jsme mohli pozorovat, duchovní a lidové písně se ovlivňovaly vzájemně. Vlivem kancionálových duchovních písní docházelo k pronikání spisovných výrazů do textů, z místní tradice do duchovních textů zase nářeční prvky a melodické ozdoby. Tím se rozkryla další otázka melodických ozdob v duchovní písni interpretované v lidovém prostředí. Důležité je rozlišit, do jaké míry jsou melodické ozdoby znakem individuálního zásahu interpreta a nakolik se jedná o regionální specifikum. Pro zodpovězení této otázky je nutné v budoucnu porovnat duchovní písně s vnorovskými světskými písněmi.

Kateřina Smékalová (Felix.KS@seznam.cz) studuje v doktorském studijním programu na Ústavu hudební vědy Filozofické fakulty Masarykovy university v Brně a v současné době je odborným pracovníkem Hudební knihovny MZK.

\section{ABSTRACT \\ HYNEK BÍM - A COLLECTION OF SACRED SONGS FROM VNOROVY}

The aim of this thesis is to examine in detail a collection of church songs which was collected by Hynek Bím during 1911 in Vnorovy. Today, the source is stored in the archives of the EU AVČR in Brno under the signature A1084. A substantial part of this thesis is concerned with the analysis of the church songs and identification of their variants. For these purposes it was necessary to use other resources. One of them is Jan Josef Božan's hymnbook Slaviček rájský from 1719 which serves as a source for inquiry about the changes of the church songs' textual and melodic component in the folk environment. Although the songs in Bím's collection are classified according to the date when they were recorded, this thesis sorts the songs out with regard to their function. There are advent songs, lent songs, pilgrim songs, songs praising saints, banqueting songs, and one wedding song. Another general section is created for songs which are not related to the church year as it is in Slaviček rájský.

\section{Key words}

folk song, sacred song, Vnorovy, Leoš Janáček, František Bartoš, Hynek Bím

\section{Bibliography}

BARTOŠ, František - JANÁČEK, Leoš. Národní písně moravské v nově nasbírané. Praha: Česká akademie císaře Františka Josefa pro vědy, slovesnost a umění, 1899-1901.

BARTOŠ, František - JANÁČEK, Leoš. Národni písně moravské v nově nasbirané. Praha: Česká akademie císaře Františka Josefa pro vědy, slovesnost a umění, 1899-1901.

68 Např. písně Ó, dobrú noc Bože věčný se nenachází v kancionálu Salavičé rajský, ale téměř shodný nápěv můžeme nalézt právě v Bartošových sbírkách (viz BARTOŠ - JANÁČEK, op. cit., s. 2002). 
BARTOŠ, František. Národní písně moravské v nově nasbírané. Brno: Matice moravská, 1889.

BÍM, Hynek. Lidové písně z hanáckého Slovácka. Jiří Vysloužil (ed.). Klobouky u Brna: Městský úřad, 1998.

BÍM, Hynek. Lidové pisně z Hustopečska. Praha: Orbis, 1950.

BÍM, Hynek. Slovenské národné piesne. Praha: ČOS, 1947.

BÍM, Hynek. Valašské a Slovenské lidové písně. Praha: SNKLHU, 1954.

BÍM, Hynek. Zpěvník národních pisní. Praha: Nakladatelství Československé obce sokolské, 1946.

BROUČEK, Stanislav - JEŘÁBEK, Richard (eds.). Lidová kultura: národopisná encyklopedie Čech, Moravy a Slezska. Sv. 3, Praha: Mladá fronta, 2007.

ČERNÍK, Josef. Umění hudební. Moravské Slovensko. Sv. 2. In Národopis lidu českoslovanského. Díl 1. Praha: Národopisné muzeum českoslovanské, 1922.

DVORSKÝ, Josef. Vnorovské proměny: 750 let: 1249-1999. Vnorovy: Obecní úřad Vnorovy, 1999.

EÚ AVČR, Brno - Kostelni písně ze Znorov: Bímova předmluva ke vnorovským kostelním písním, sign. A1084.

HOSTINSKÝ, Otakar. 36 nápěvů světských písní českého lidu XVI. století. Praha: Státní nakladatelství krásné literatury, hudby a umění, 1957.

JANÁČEK, Leoš - VÁŠ́A, Pavel. Moravské pisně milostné. Praha: Státní ústav pro lidovou píseň v ČSR, 1930 - 1937.

JANÁČEK, Leoš. O lidové písni a lidové hudbě: dokumenty a studie. Jiř́i Vysloužil (ed.). Praha: Státní nakladatelství krásné literatury, hudby a umění, 1955, s. 57-78.

JELÍNEK, Josef - MOTYČKA, Tarzicius Martin. Duchovni a historické dèdictví farnosti svaté Alžběty Durynské ve Vnorovech. Vnorovy: Rímskokatolická farnost, 2009.

JUNGBAUER, Gustav. Volkslieder aus dem Böhmerwalde. Díl 1, 2. Praha: Ústav pro lidovou píseň v ČSR, 1930, 1937.

Kol. autorů. Nejstarši zvukové záznamy moravského a slovenského lidového zpěvu (z folkloristické činnosti Leoše Janáčka a jeho spolupracovníků). Brno: Gnosis, 1998.

KOSEK, Pavel - MALURA, Jan. Slaviček rájský Jana Josefa Božana a česká duchovní píseñ vrcholného středověku. Brno: Host, 1999.

KYSELKOVÁ, Františka. Jak jsem sbirala národní písně. Brno, 1941.

MALURA, Jan. Pisně pobělohorských exulantů. Praha: Academia, 2010.

MALÝ, František. Salve regina, poutnický kancionál pro poutě a laické pobožnosti, Brno: Salve, 1992.

SMÉKALOVÁ, Kateřina. České kancionály 1. poloviny 16. století. Techniky a typy redakčnich úprav jejich obsahů. Diplomová práce. Brno: Masarykova univerzita. Filozofická fakulta. Ústav hudební vědy, 2009.

SMÉKALOVÁ, Kateřina. Sbirka duchovních písní z Vnorov. Brno: Masarykova univerzita. Filozofická fakulta. Ústave evropské etnologie, 2009.

ŠKARPOVÁ, Marie. Kancionál český M. V. Šteyera - návrh českého hymnografického kánonu. Diplomová práce. Brno: Masarykova univerzita. Filozofická fakulta. Ústav české literatury a knihovnictví, 2006.

ŠTĚDROŇ, Miloš. Janáčkovy poznámky k frankfurtskému festivalu. Opus musicum 3, 1991, s. $8-10$.

TONCROVÁ, Dana. Korespondence Leoše Janáčka s Hynkem Bímem. Diplomová práce. Brno: Masarykova univerzita. Filozofická fakulta. Ústav hudební vědy, 1999.

ÚLEHLA, Vladimír. Živá píseñ. Praha: F. Borový, 1949.

VETTERL, Karel. Lidové písně a tance z Valašskokloboucka. 1, 2. Praha: ČSAV, 1955, 1960.

VETTERL, Karel. Nad dílem Hynka Bíma. Český lid 46, 1959, s. 177.

VYSLOUŽIL, Jiří. Hynek Bím (K osmdesátinám významného sběratele lidových písní). Český lid 41, 1954.

ZÍBRT, Čeněk. J. S. Baar, farář ořechovský, na svatbě v Řeporyjích u Prahy. Český lid, 26, 1907, s. $140-148$. 
